\title{
PERSPEKTIF PERSONALITI DAN PSIKOLOGI TERHADAP DENIM JEANS LELAKI DALAM MUZIK DAN FESYEN DI ERA REVOLUSI PERINDUSTRIAN KE-4
}

\author{
AZWADY MUSTAPHA * \\ NUR IZZATY MOHD ROSLAN ** \\ azwady.m@umk.edu.my*, nurizzatymohdroslan@gmail.com**
}

\begin{abstract}
Abstrak
Sifat psikologi menerangkan cara di mana setiap orang berbeza antara satu sama lain. Ini merupakan konsep Maslow dan keperluan psikologi. Sehubungan itu, ramai artis Malaysia menggemari seluar jeans semasa membuat tayangan pentas, penggambaran drama atau filem dan kehidupan seharian. Sebagai contoh, artis dan muzik yang dipersembahkan memainkan peranan besar ke arah fesyen. 40 responden lelaki dipilih secara rawak berumur antara 23 hingga 30 tahun berhampiran Kuala Lumpur. Objektifnya adalah bagi memahami gaya pemotongan yang sesuai dengan dapat membezakan pelbagai gaya yang sedia ada dan melambangkan keperibadian lelaki terhadap penggayaan seluar jeans. Kajian ini menekankan kepada pelbagai penggayaan seluar jeans dalam mencerminkan keperibadian lelaki. Data dianalisis menggunakan kaedah kualitatif. Kajian ini diharap dapat memberi kefahaman tentang keperibadian terhadap refleksi identiti diri lelaki di Kuala Lumpur menggunakan kaedah Pakej Statistik Sains Sosial (SPSS).
\end{abstract}

Kata Kunci: Data Kuantitatif, Gaya Jeans, Identiti Diri, Muzik Psikologi, Sifat Psikologi 


\title{
PERSONALITY AND PSYCHOLOGICAL PERSPECTIVES ON MEN'S DENIM JEANS IN MUSIC AND FASHION OF THE $4^{\text {TH }}$ INDUSTRIAL REVOLUTION
}

\author{
AZWADY MUSTAPHA * \\ NUR IZZATY MOHD ROSLAN ** \\ azwady.m@umk.edu.my*,nurizzatymohdroslan@gmail.com**
}

\begin{abstract}
Psychological trait describes ways in which people are different from each other. This follows Maslow concepts and psychological needs. In relation, many Malaysian artists favour jeans wearing during stage show, drama shooting or film and daily life. For instance, both the artist and the music they sing can play a huge role in which direction the fashion industry moves. 40 male respondents are randomly selected, aged from 23 to 30 years old near Kuala Lumpur. The objectives are to understand the cutting styles that fits the person by being able to differentiate various styles available reflecting men's personality towards jeans styles. By undertaking a quantitative method, the study was able to provide an insight into the personality of self-identity reflection towards men in Kuala Lumpur using Statistical Package for the Social Sciences (SPSS). The study emphasizes on whether men's personality was reflected by different styles of denim jeans.
\end{abstract}

Keywords: Jeans Styles, Music, Psychological, Psychological Trait, Quantitative Data, SelfIdentity

* Senior Lecturer at Faculty of Creative Technology and Heritage, Universiti Malaysia Kelantan, Malaysia

** Student at Faculty of Creative Technology and Heritage, Universiti Malaysia Kelantan, Malaysia 
The fashion world as we know it is in a moment of flux. In the midst of a gamechanging technological revolution, greater consideration is being given to the skill safely tucked away at fashion's heart, while consumers are increasingly questioning the emotional value of fashion (Emma, 2017). We often wonder how personality is studied scientifically. What is Personality? How is Personality studied and assessed? Personality is that unique combination of emotional, behavioural and attitudinal responses and reactionary patterns unique to a person. When it comes to jeans or denim, it's possible to separate them especially from men. Men nowadays have at least 4 or 5 sheets of denim pants in their wardrobe (Antonio, 2010). Although nowadays many international denim brands are control the market such as Calvin Klein, Diesel and others.

Psychology plays a role in clothing preferences, be it due to privacy or modesty. Most closely related to this reason is wearing of clothes because of a desire to be attractive. In psychologically good clothes, an individual is taking an action to impress and allow other people to react to it positively. In return, the positive feedback able to give them strength and further increase their self-confidence. In other words, clothes are the mirror of someone's personalities. Our identity comes almost exclusively from communication with others. As psychologists Arthur Combs and Donald Snygg (1959) put it:

The self is essentially a social product arising out of experience with people...We learn the most significant and fundamental facts about selves from"reflected appraisals", inferences about ourselves made as a consequence of the ways we perceive others behaving toward us. ${ }^{1}$

In conclusion, people's perspectives reflected an individual's behaviour when it comes to self-expression. We put ourselves in the position of other people and then in our mind's eye, view ourselves as we imagine they see us. In the modern age society, people are becoming more advanced in technology savvy especially in the communication arena. The internet has become a platform of real time communication and the number of Internet users has increased in the recent years. Cattell (mid-1960's) believed that true factors of personality should be found across different types of data and can be qualified with developing a strong experimental strategy for identifying the basic dimensions of personality and trait approach to personality. According to Cattell (1970), he believed that true factors of personality should be found across different types of data. Although the result does not always produce an identical numbers of personality factors, consistency able to lend credibility to Cattell's system which consists of 16 personality factors. Cattell's taxonomy of 16 is among the largest in terms of the number of factors identified as basic traits. People have been involved with circles for centuries and also fascinated personality psychologist as possible representations of the personality scope.

${ }^{1}$ Arthur W. Combs and Donald Snygg, Individual Behavior, rev. ed. (New York: Harper \& Row, 1959), p 134. 


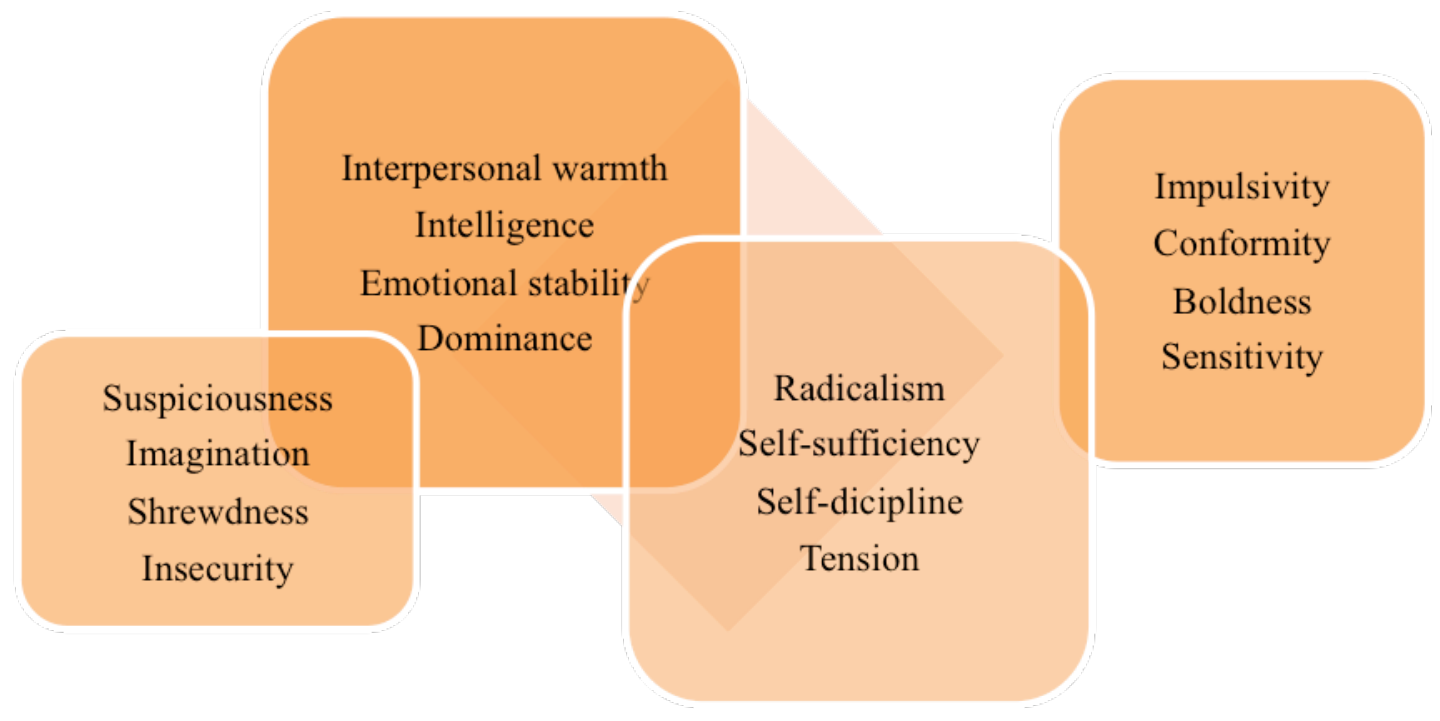

Figure 1: The 16 Personality Factor Scale

(Source: Personality Psychology Domains of Knowledge about Human Nature, 2005)

Conferring to Kluckhohn \& Murray (1948), these three levels are well summarized by them on culture and personality in which states every human being is in certain respects:

1. Like all others (the human nature level)

2. Like some others (the level of individual and group differences)

3. Like no others (the individual uniqueness level)

These distinctions is that the first level refers to "universals" which we are all alike, the middle level refers to "particulars" in the ways in which are like some people but unlike others and the third level refers to "uniqueness" means the ways in which are unlike any other person). The first level of personality analysis describes human nature in general that the traits and mechanism of personality are typical of species and are controlled by everyone or nearly everyone. There are many ways in which each person is like every other person and by understanding those ways may achieve an understanding of the general principles of human nature. The second level of personality analysis relates to individuals and group differences. These are dimensions of individual differences in each person is like some other people e.g., extraverts, sensation seekers and high self-esteem persons (Matthews et al, 2003).

Personality can also be observed by studying differences between groups that is people in one group may have certain personality features in mutual make that group of people different from other groups. Another important set of differences studied by personality psychologists concerns those between men and women. Men are responsible for most of the violence in society. One goal of personality psychology is to understand why certain aspects of personality are differentiated along group lines such as understanding how and why women are different from men and why persons from one culture are different from persons from another culture. 
Fashion affects music, and music affects fashion. Television and movies inspire fashion and because fashion is all-incorporating. There are many aspects of the industry that need new talent constantly. History repeats itself not only with world events but with fashion, "fashion is evolutionary not revolutionary". In other verses, fashion changes over time and is not necessarily new but a basic design is changed to form new fashions. According to Abraham Lincoln (1839):

What has once happened will invariably happen again, when the same circumstances which combined to produce it, shall again combine in the same way (pp 64).

History is an important aspect in fashion design and fashion merchandising because fashion is repeated which means styles popular in one time period will likely become popular again. Bell-bottoms are a good example of the cyclical nature of fashion. They were popular in the 1960s and again in the late 1990s, although the bell-bottoms popular in the late 1990s did not look exactly the same as those in the 1960s, the inspiration was taken from that period. Industrialization had an impact because clothing no longer had to be made by hand and could be made by machines that produced clothing faster and less expensively. Nevertheless industrialization changed fashion in several other ways as well.

In the late 1800s, Levi Strauss and Jacob Davis developed know as a fashion staple, jeans. Observing that many men ripped their pants in factory jobs, mainly at the pockets Davis invented the rivet which was applied to points of strain on pants. While denim pants had been around before Strauss and Davis, the use of rivets made the jeans more suited to the needs of workers in the industrialization era. Economics times, war and especially social influences have influenced fashion over the last century. Understanding the events of each decade helps 'fashionistas' to better predict trends.

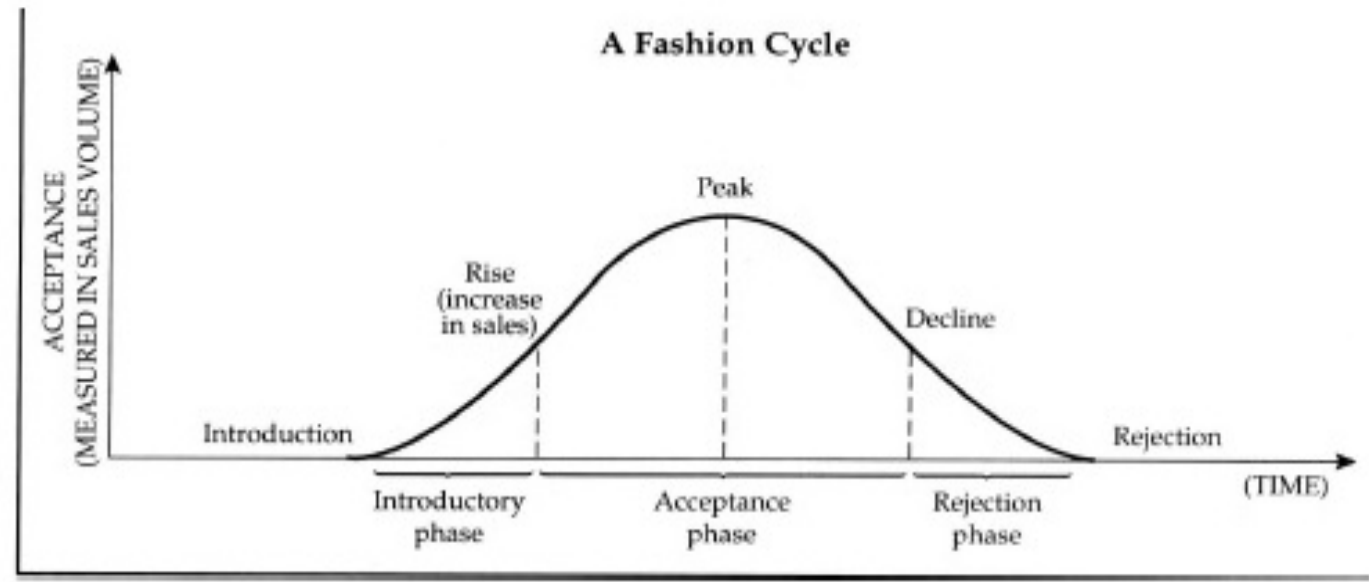

Figure 2: The Fashion Cycle

(Source: Core Concepts in Fashion, 2008)

Fashion means the style or styles of clothing and accessories worn at a particular group of people. The point is that fashion has always been changing and evolving at any time in the past may be history that change was usually dramatic. The evolution of fashion is an exciting one, full of inovations and imitiations. The technique in which fashion changes is 
usually described as a fashion cycle and also difficult to categorize or theorize about fashion without overgeneralizing. Despite of that, the fashion cycle is usually shown as a bell shaped curve encompassing in five stages such introduction (indecent/shameless), rise in popularity (outré), peak of popularity (smart), decline in popularity (dowdy/hideous) and rejection (ridiculous).

The introduction phase is when clothing is introduced at a high price level. The next new fashion may be introduced by a producer in the form of a new style, color or texture. This testing period comes at the beginning of the buying cycle of fashion merchandise which agrees with the introduction stage of the fashion cycle. In the growth phase, fashion followers will accept the garment worn by the fashion leaders. Once that acceptance has occurred, manufacturers will then copy the garment and sell it for a less expensive price. During the rise stage of a new original design, many retailers offer knockoffs which is version of the original designer style duplicated by manufacturers. Modifications have been made but characteristic features of the original such as use of textured fabric may be retained in the adaption. The garment can be found at almost any retailer and it is accepted by the mass market in the peak phase. In addition, prices are often reduced in many retail stores (Philip, 1987). This stage of a fashion may be extanded in two ways:

1. If fashion becomes accepted as a classic, it settles into a fairly steady sales patern.

2. If new details of design, color or texture are repeatedly intriduced and interest in the fashion may be kept active longer.

Ultimately, consumers bored of the garment and start to look for something new. During the decline phase, fashion leaders have already moved on to new styles. As a fashion starts to decline, consumers may still be wearing it but they are no longer willing to buy it at reguar price. At this stage, the style may be found in cheap stores at prices far below in what the style commanded in earlier stages. The rejection phase is when most consumers will no longer buy the product, even on sale and have moved on to new styles. It is important to note that there are many consumers who are willing to buy clothing that is considered out of a date. While these consumers are not considered stylish do provide income for retailers. The cycle garments go through and the possible categories of fashion products will assist the merchandiser in the process of buying. In order to efficiently buy, one must understand not only the concepts in buying but also the process and duties a fashion merchandiser must perform (Encyclopaedia Britannica, Inc 2021).

How music influences fashion? The relationship between fashion and popular music is one of plentiful and mutual creativity. Common influences have resulted in some of the most dynamic apparel visualizations ever created in popular culture. Some exist as memorable creations for the stage and music video such others become long-lasting fashion trends which in the culture to become significant, referential and lasting. This can make three collaborations exist. One is when fashion designers and entertainment celebrities' fashion to fit a declared project and another collaboration occurs when youth subcultures expressive themselves through fashion. The third is when the fashion industry interprets a musicled theme or trend. Music celebrities and designer collaborations have altered the course of fashion thought good examples of this relationship. The effects of these unions have been very significant. 
The outcome of many associations of the performer and the designer or stylist is usually a confirmation of the existing youth subcultural fashion. Somewhat new perspectives, new methods and new significances of fashion are made when fashion and music are linked to subcultural expression. Fashion and music capably and often independently create similar themes yet the dynamic interaction between them motivates reactions that might not have otherwise occurred. It's natural impulse to conduct the activity of objectifying popular music, youth subcultures and others. How music influenced fashion can be seen in almost every decade of last century.

The following decades exemplified how well fashion became reflective of music trends and how music was affected by fashion:
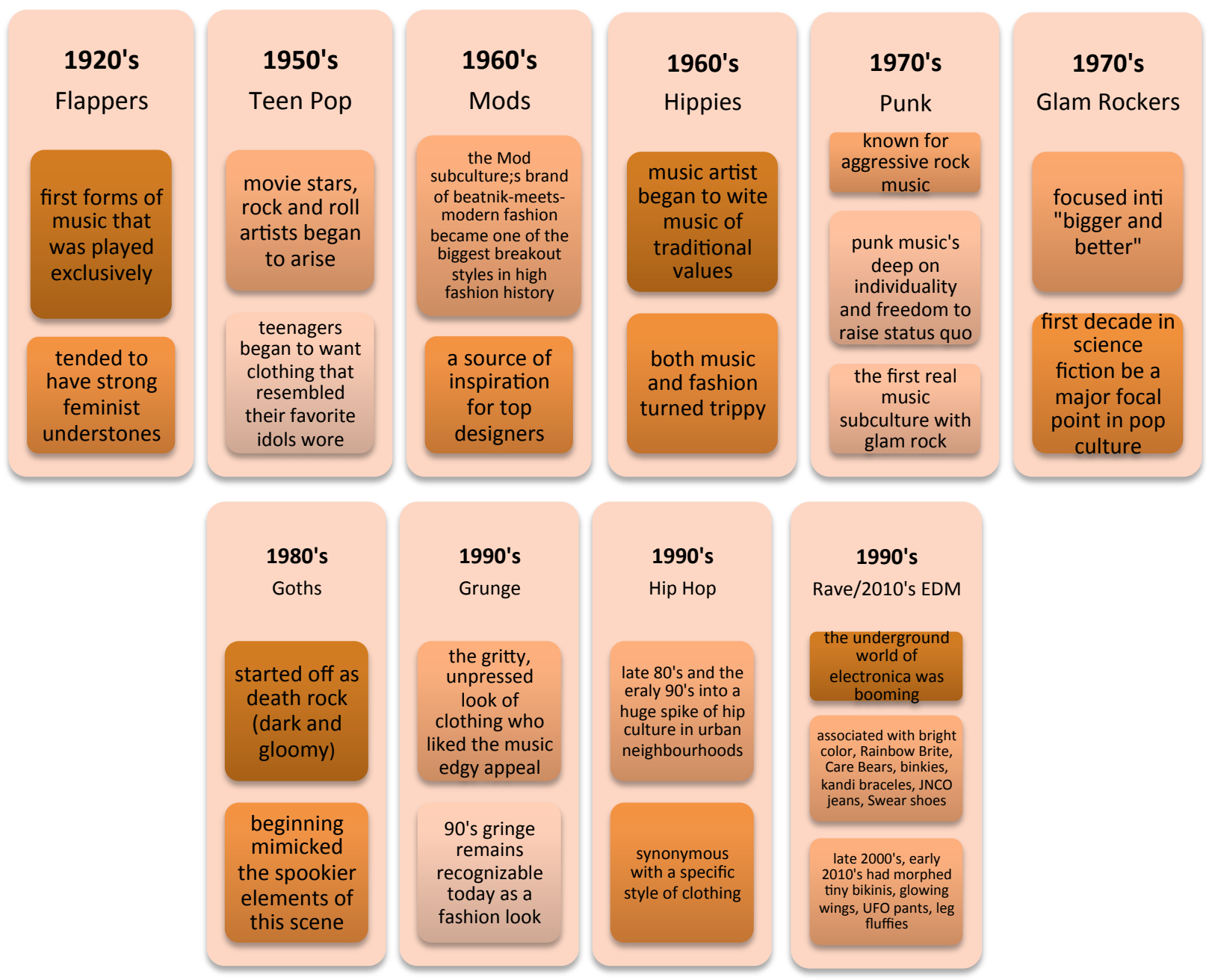

Figure 3: Music and Fashion: Intertwined Throughout the Ages

(Source: Riley Raul Reese, 2017)

This is why developments away from conventional or formalized fashion customs can only be made when the agenda is no longer centred on the commerce of fashion but is concerned with the disrespect irrationality of making fashion images. Fashion is one the clearest signs of the times and it say more about society to give it credit for. Rather than worrying about one's fashion being deemed useful, people began to see fashion is linked 
with the current musical trend. According to Riley (2017), the reason why fashion and music became so intimately linked is because music became a method of showing individuality, political beliefs and ideas rather than just standardized entertainment. This isn't a random occurrence, the reason why fashion and music became so intimately because music became a method of showing individuality, political beliefs and ideas rather than just standardized entertainment.

Music has many effects on our lives when it comes to health, feelings and moods otherwise inspires many aspects of our lives. Whether from art, movies, TV shows it can play a great role in how we do things. The effect music has on fashion has been evident throughout history. But, now with social media playing such a huge role in how things are seen and shared so that role has increased dramatically. The truth it that fashion has always been used as a way for individual expression and for that reason, both of these are intertwined and closely linked together. Nowadays, mostly are wearing skinny jeans because of the impact from indie music.

This means that both the artist and the music they sing can play a huge role in which direction the fashion industry moves. All it takes is one song to change everything. Once that song becomes popular, the fashion from the artist or band who sings that song can impact the fashion world completely. Denim jeans are depending to the impact and revolution of American society, this eventually contributed in the increasing of jeans worldwide and helped people see jeans as an authentic American icon. The business of jeans later became one of America's bigger industries.

As already known, today a denim jeans are widely seen everywhere and are not limited only to the blue color anymore (Fibre2Fashion, 2013). Denim jeans have become a way of life in America and around the globe. The assumptions pop culture influences music and same goes to music influences fashion a never-ending cycle. It's one that will always reflect what really going on in our cooperative minds. As a consequence, music will always have a special place in the world of fashion design and in the hearts of artist of every kind. 


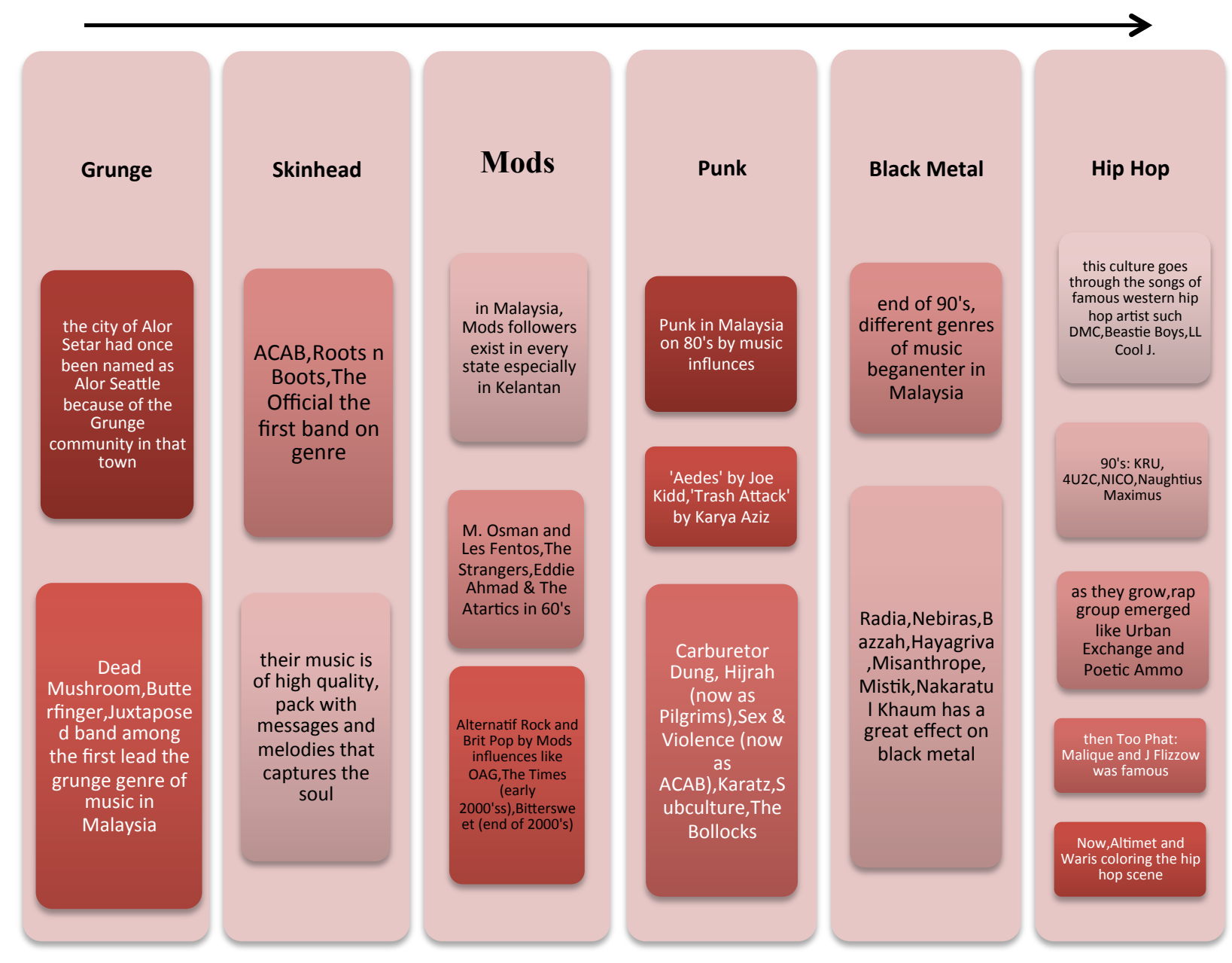

Figure 3: Popular Subculture in Malaysia

(Source: Zaima, Copyright by lluminasi.com, 2017)

\subsection{Literature Review}

\subsection{Timeline of Blue Denim Jeans}

The word "jeans" had been used since the 1600 s to describe the rough clothing worn by working men because this type of clothing was often made of durable jean or ${ }^{2}$ genes fabric from Genoa, Italy. Denim, the durable fabric which is almost always used to make modern blue jeans was originally made in Nimes, France. American manufacturers shortened the name serge de Nimes, to denim. Denim fabric was often dyed dark blue so that work clothes made from it would not show dirt and stains.

Blue jeans moved from work clothes to the preferred pants of rebellious young men during the 1950's and 1960's to high fashion items. By the end of the twentieth century, a comfortable pair of jeans had become a necessity in the

\footnotetext{
${ }^{2}$ Genes : Genetic material, fabric Genomics
} 
casual wardrobe of both men and women. Considered as a men's fashion icon, Anuar Zain's (2017) “just use something touched with each other's shape, outside there's always something for someone either in terms of design or size regardless of body shape". Anuar also argued, every men should have these items in his wardrobe such as a black T-shirt, a pair of blue jeans and a pair of white snaps because it's like a basic dress that all should exist. Less is more. "If you get stuck, just use this basic it will definitely look stylish depending on the body shape" (Anuar, 2017).

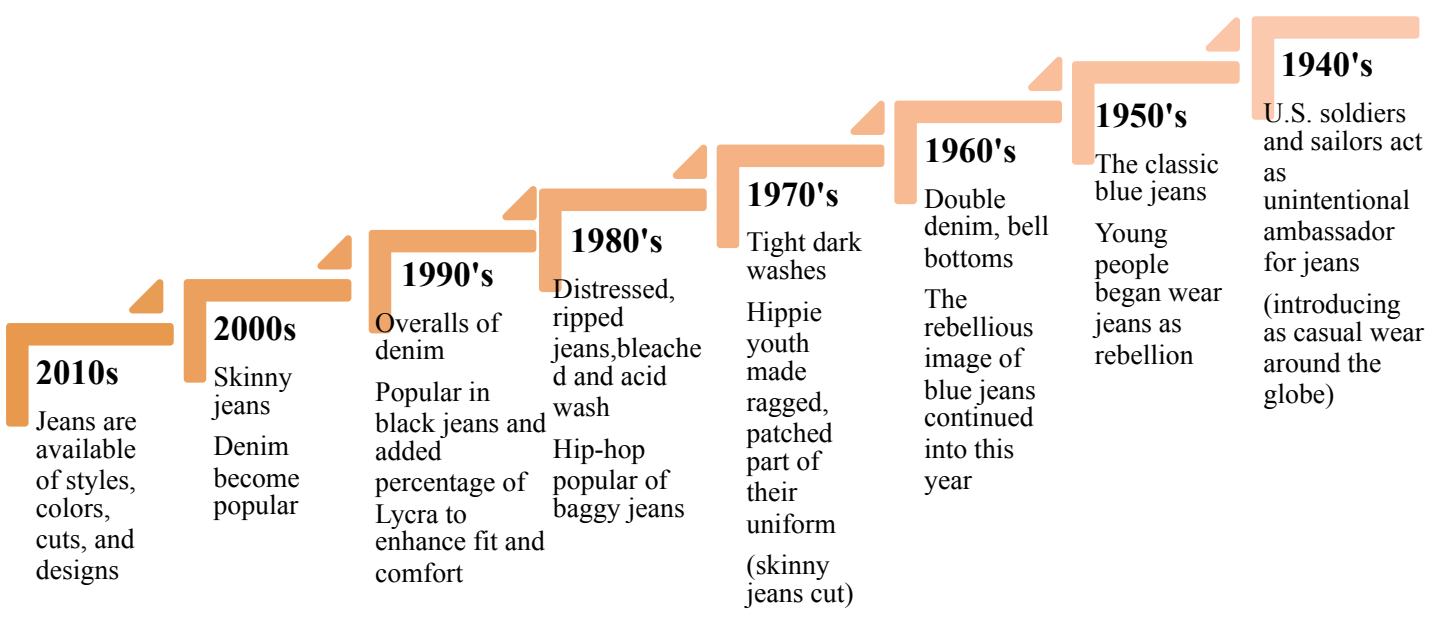

Figure 3: Timeline of Denim Jeans

(Source: Core Concepts in Fashion, 2008)

Jeans became so popular among cowboys that during the 1930's. In the 1920's, 1930's, and 1940's many people began spending their spare time at the movies, where popular Western films found glamour and romance in the adventures of the cowboys. During the 1950's many young people began to wear jeans when they saw them on rebellious young American film stars. Blue jeans were identified with American culture that they were placed in the American culture that they were placed in the American exhibition at the 1958 World's Fair. Around the same time, the first jeans were exported to Europe (Fashion, Costume and Culture, $2^{\text {nd }}$ Edition, 2000).

The rebellious image of blue jeans continued into the 1960's and 1970's, when the hippie youth made ragged, patched blue jeans part of their uniform. Jeans had become popular but were still mainly worn by working people or the young. During the 1980's this began to change as famous fashion designers created designer jeans which were expansive and became one of the most usually worn items of clothing in the world. The $20^{\text {th }}$ century most iconic garment as blue jeans is for designers to experiment with and challenge. Today, jeans are available in a varied range of styles, colors, cuts and designs. Fashion change often, in some years very loose or baggy jeans are popular while in other years, very tight-fitting jeans or skinnies are fashionable. Other styles that have popularity include bell-bottoms, boot-cut, straight fit, stretch, low-rise, highwaisted and many more. 
According to Hazita Azman, Bahiyah Abdul Hamid \& Zarina Othman (2011) states Malaysian Financial Well Being Instrument develop in 2006; their research reveals the current level of financial well-being achieved by youths in Malaysia correlated with age, gender and education qualifications quite significantly. Thus, jeans choice should be related to an individual's personality or identity. Perhaps, clothing choice may reflect things other than identity or may reflect nothing. There appears to be an underlying assumption that all clothing represents a person's identity. Evaluation of the potential role of young people in a transition towards a sustainable consumption lifestyle is important especially with the influence of media and globalization in determining their aspirations and values.

Over $50 \%$ of denim is produced in Asia specifically China, India and Bangladesh. Blue jeans today didn't come about until the middle of the nineteenth century. Blue jeans started becoming popular among young people in the 1950s. In the year 1957, 150 million pairs were sold worldwide (Fibre2Fashion, 2013). This increasing trend continued until 1981 and jeans manufacturers were effectively guaranteed annual sales increases. The first name for jeans are originally called 'waist overall'. The terms 'jeans' became popular in 1960's when the jeans wearing used from mainly workers wearing them for practical reasons to the baby boomers ${ }^{3}$ who helped reach the level of popularity they are today.

The transformative sameness of jeans was highlighted by the details of their variations and the simultaneous presence of different fashionable or cuts. Jeans are not only unisex items and they are also perceived as potentially very sexy. Jeans denim optimal is related to an individual's personality or identity. The identity of men characteristics described about themselves sowed statistically significant when only exposed to an outfit of jeans chosen by individuals trying to reflect their personality. Jeans may be having a semiotic function that signals something of the social identity of its wearer.

${ }^{3}$ Baby boomers : Use birth years starting from the early to mid-1940's and ending anywhere 1960-1964 

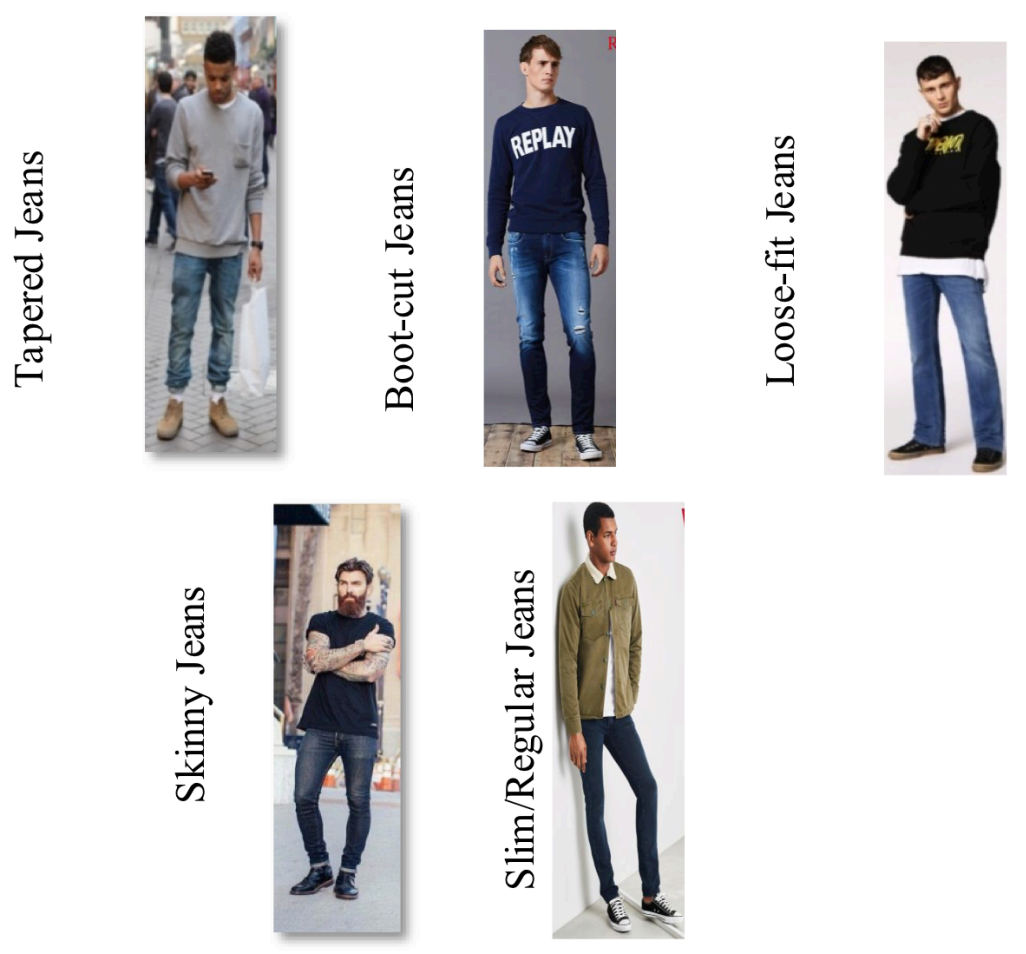

Figure 4: Jeans Denim towards Personality or Identity Reflection Source: Common Perfect Pair of Jeans, Antonio (2012)

Yet, it must also be said that this relationship is not as strong as the experimental and theoretical work in this area suggests. Under the best conditions, in which the identity characteristics were selected to be related and when jeans were chosen to be representative of the individual that be respondent are achieved statistical significance. The identity of the individual may be label of jeans was necessarily selected by the men to be representative of him and sometimes a pair of jeans is just a pair of jeans not a political or value statement. The connection between jeans and identity were studied in best situations such as represented the person based on the assumptions. In addition, Workman (1988) influentially demonstrated that brand labels communicated perceived aspects of identity. However, Workman showed that observers think jeans carry meaning and not show that the meaning of the brand labels were really related to aspects of the personality or identity of the person who choose to wear that brand.

For example, slate blue means you're loyal and dependable like the classic denim. 'Men have always been preoccupied with their appearance, historically, even more so than women' (Wilson, 2014). What is style? Your personal style is a combination of the clothes you like to wear and the way you style. Fashion is hard word to describe but it generally refers to clothing and trends. Fashion includes all aspects and styles of clothing although it is usually used when referring to items that are trendy or popular with a large group of people. 
Clothing can satisfy the psychological need to belong a group (Maslow, 19081970). Both men and women 'place' great value on clothing and appearance. After the war ended, many of the factories that created uniforms began massproducing ready to wear men's garments such as denim jeans and shirts (A history of Fashion). One of the important parts of personal style is knowing what looks good on you, knowing how to identity your body type will help choose clothing items and silhouettes that highlight best features. Yves Saint Lauren (2018) said:

I wish I had invented blue jeans. They have expression, modesty, sex appeal, simplicity- all I hope for in my shoes

Lauren explained that he really wants to create blue jeans and he desire to have feeling, politeness, sexual longing and easy life like everyone need. Fashion becomes implicated in constructions and reconstructions of identity.

Personality can be defined as the total unique characteristics that differentiate an individual, especially his or her behavioral and emotional tendencies. Men who have negative attitudes about their bodies and appearance report a wide array of psychological and health issues (Cafri et al., 2005; Labre, 2002; McCabe \& Ricciardelli, 2004).Body image isn't just a female issue. Men have just as much anxiety about their looks as women do according to a new study published in the journal Body Image. What's more, body image was the second-highest predictor of overall happiness for men even ahead of their love life. Building a confidence will give a better impression to everyone you meet.The fact that jeans became regarded as socially and culturally "unmarked", what we are calling neutral or multi-functional helps to explain how such a piece of clothing can relieve the concern of having to choose what to wear the other thesis developed by Miller and Woodward in their Manifesto for the Study of Denim (2007). Jeans as "subject visors" as objects that activate processes of self-positioning, self-determination and self-expression even if this self-expression takes the form of neutrality or non-remarkableness. According to Sullivan 2006; Ewen \& Ewen 1992; Berger 2009) said the price of jeans started to rise in the 1980s when fashion designers seized on this category of trousers, leading to a virtual jeans renaissance through the development of new product varieties adapted to a vast array of situations. In the last thirsty years that jeans became acceptable in most social situations even changing conditions.

Now in Malaysia, there are a few of companies that have started actively in the business of denim jeans and also some of have begun to expand overseas such as Indonesia. Since founding in 2012, a Raw Denim House (RDH), one of local custom-made jeans maker has rocked the international fashion and hometowns. Based in Besut, Terengganu RDH cares about its products with great care given to every detail in honour of its identity and heritage. The 'chicken claw' symbol as a brand on the back of the jeans reflects the local legend that tells how 'Besut' became district in the state of Terengganu, in mark with successful efforts to domain the original identity that embodies the philosophy of the life of 'Besut-born children' in their special work. According to 
founder of $\mathrm{RDH}$, Ahmad Safuan Nizam Kamarudin who recently received the 'Award Sultan of Terengganu' from the Sultan of Terengganu, Sultan Mizan Zainal Abidin in honour of Maal Hijrah that are really interested in jeans especially the artisanal aspects of denim jeans. They also focused on maintaining the authenticity of jeans using classic machines from the 1940's because can see this venture as an art form where each piece of work created is unique and different from others plus also want to maintain the value of artisan in the making of jeans.

Most of the machines used to manufacture pants from the United States and Japan because they respect the philosophy of the production of pants. Around 17 machines including the Reece 101 and the Union Special made from the 1940 's to the 1950's have been used a beautiful effect on the pants after long wear. Due to the current shortage of sewing machines, they had to limit production to about 30 pieces a month to ensure quality.

Afiq Iskandar Zainal Ariffin (2018) well-known as Afiq "Amber" Iskandar a Founder of Denim Company, Tarik Jeans, Co- Founder Nusantara Denims and the guitarist member of the band Oh Chentaku. Music and fashion go hand in hand which is could explain why musician Afiq Iskandar is not involved in two bands but also owns a clothing brand and store. He created Tarik Jeans, "The word 'Tarik' is something all Malaysians understand and want my apparel to cater to them". The store carries several South East Asian denim and leather brands as well. Tarik Jeans is a street wear premium denim label the Malaysian and Nusantara identity of diversity founded in Perai, Penang (2010) but now the company has continued business in Petaling Jaya, Selangor. Fashion is filled with philosophy to connect with the denim lovers of all ages and background. Despite the growing fashion in Malaysia and internal changes, Tarik Jeans have not dropped of their pursuit of educating a healthy denim scene in our community. Malaysian able to choose Tarik's denim, which maintain presents culture and improved version. Afiq Iskandar (2015) said that Tarik Jeans started by identifying with a Malaysian citizen. 
Table 1: Jeans Denim towards Personality or Identity Reflection Source: Common Perfect Pair of Jeans, Antonio (2012)

\begin{tabular}{|c|c|c|}
\hline JEANS STYLES & $\begin{array}{l}\text { STATEMENTI } \\
\text { EXPLANATION }\end{array}$ & $\begin{array}{c}\text { PERSONALITYI } \\
\text { IDENTITY REFLECTION }\end{array}$ \\
\hline $\begin{array}{l}\text { 1. Slim/Regular } \\
\text { jeans }\end{array}$ & $\begin{array}{c}\text { The perfect jeans for thin men. } \\
\text { Body types: athletic and thin men, } \\
\text { short and tall men and men of any } \\
\text { age. }\end{array}$ & $\begin{array}{l}\text { - More of a classic fit which } \\
\text { is ideal for the everyday } \\
\text { modern gent. } \\
\text { - In life, have a handful of } \\
\text { passions, a tight group of } \\
\text { downtowns by fusing form } \\
\text { and function with this cut. }\end{array}$ \\
\hline 2. Skinny jeans & $\begin{array}{c}\text { Body types: very thin men, short } \\
\text { men and trendsetter under } 35 \\
\text { years }\end{array}$ & $\begin{array}{l}\text { Young heart and } \\
\text { confident. } \\
\text { - Men are who really on top } \\
\text { of all the latest trends that } \\
\text { want to look good and } \\
\text { stand out of the crowd. }\end{array}$ \\
\hline 3. Boot-cut jeans & $\begin{array}{l}\text { The boot-cut jeans are baggier all } \\
\text { the way down with a slight flare at } \\
\text { the bottom. } \\
\text { Body types: all figure types and } \\
\text { men who dress casually }\end{array}$ & $\begin{array}{l}\text { Make a flattering look but } \\
\text { not exactly trendsetting. }\end{array}$ \\
\hline 4. Loose-fit jeans & $\begin{array}{l}\text { Body type: all figure types and } \\
\text { good on thickset men }\end{array}$ & - Looks more relax. \\
\hline 5. Tapered jeans & $\begin{array}{l}\text { Give the skinny look from the } \\
\text { quads down but fit better around } \\
\text { the waist for better look. } \\
\text { Looser at the top of the leg and } \\
\text { then taper to a more fitted shape } \\
\text { from the knee downwards. } \\
\text { Body types: young trendsetter, } \\
\text { fans of street wear, all figure types }\end{array}$ & $\begin{array}{c}\text { Look fantastic. } \\
\text { - Some tricks that the } \\
\text { stylists know }\end{array}$ \\
\hline JEANS STYLES & $\begin{array}{l}\text { STATEMENT/ } \\
\text { EXPLANATION }\end{array}$ & $\begin{array}{c}\text { PERSONALITYI } \\
\text { IDENTITY REFLECTION }\end{array}$ \\
\hline $\begin{array}{c}\text { 6. Slim/Regular } \\
\text { jeans }\end{array}$ & $\begin{array}{c}\text { The perfect jeans for thin men. } \\
\text { Body types: athletic and thin men, } \\
\text { short and tall men and men of any } \\
\text { age. }\end{array}$ & $\begin{array}{l}\text { - } \quad \begin{array}{c}\text { More of a classic fit which } \\
\text { is ideal for the everyday } \\
\text { modern gent. }\end{array} \\
\text { - In life, have a handful of } \\
\text { passions, a tight group of } \\
\text { downtowns by fusing form } \\
\text { and function with this cut. }\end{array}$ \\
\hline 7. Skinny jeans & $\begin{array}{c}\text { Body types: very thin men, short } \\
\text { men and trendsetter under } 35 \\
\text { years }\end{array}$ & $\begin{array}{l}\text { Young heart and } \\
\text { confident. } \\
\text { - Men are who really on top } \\
\text { of all the latest trends that } \\
\text { want to look good and } \\
\text { stand out of the crowd. }\end{array}$ \\
\hline 8. Boot-cut jeans & $\begin{array}{l}\text { The boot-cut jeans are baggier all } \\
\text { the way down with a slight flare at } \\
\text { the bottom. } \\
\text { Body types: all figure types and } \\
\text { men who dress casually }\end{array}$ & $\begin{array}{l}\text { - Make a flattering look but } \\
\text { not exactly trendsetting. }\end{array}$ \\
\hline
\end{tabular}




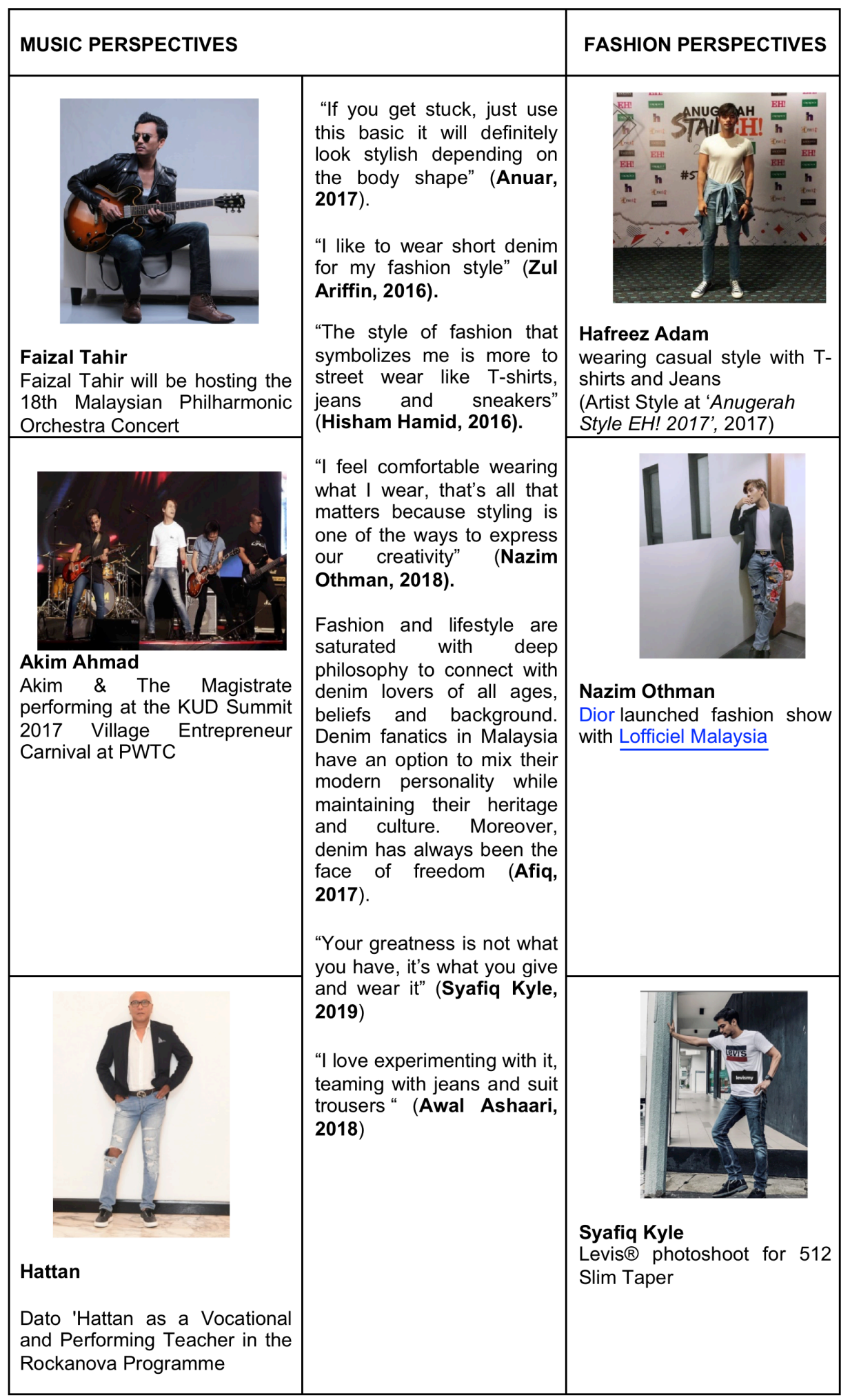

Figure 5: An Artist Perspectives of Denim Jeans towards Personality or Identity Reflection

Source: Instagram and Article (2017) 


\subsection{Fashions and Music}

As soon as a trend is spotted within the music industry, be it a rise in urban sounds or a revival of electronic music will partially be followed by the same trend popping up in the fashion industry in some way or another. The music and fashion relationship is complex and how the music industry has been an influence on the fashion industry over the years from the grunge era to the recent revival of grime. Music contributes in diverse ways to the development of innovative fashion products. According to Bramley (2015), music should play a control role in a fashion brand's identity. Both of music and fashion are provides identity-building features which in combination to form a certain lifestyle. Musicians also influence fashion with their personal style.

Different scenarios for fashion retail were found. Such example, in the case of Nike by the brands active and dynamic core values ("Just Do It"). This emotional reaction on the fit of music and brand results in a strengthened customer-brand of relationship. Soh et al. (2015), examined the influenced of background music on the durance of stay by Malaysian consumers in stores. It was conducted in 2013 and considered multiple retail settings such as flower shops, supermarkets, restaurants, bookstores and fashion retail. The study was established to show whether background music has a positive relation with the durance of stay in stores.

Regarding fashion, the speed of music does not have an influence on the length of stay by Malaysian customers in a fashion store. Malaysian consumers put a stronger focus on the selection of the clothes rather than they are listening to music while shopping. The definition of fashion furthermore only comprises apparel, footwear and accessories. Fashion becomes implicated in constructions and reconstructions of identity. Meanwhile, outside the home in the current globalized economy, youth in Malaysia face an increasingly complex financial world. According to Hazita Azman, Bahiyah Abdul Hamid \& Zarina Othman (2011) states Malaysian Financial Well Being Instrument develop in 2006, their research reveals the current level of financial well-being achieved by youths in Malaysia correlated with age, gender and education qualifications quite significantly.

Thus, jeans choice should be related to an individual's personality or identity. Perhaps, clothing choice may reflect things other than identity or may reflect nothing. There appears to be an underlying assumption that all clothing represents a person's identity. Evaluation of the potential role of young people in a transition towards a sustainable consumption lifestyle is important especially with the influence of media and globalization in determining their aspirations and values.

The transformative sameness of jeans was highlighted by the details of their variations and the simultaneous presence of different fashionable or cuts. Jeans denim optimal be related to an individual's personality or identity. Jeans represent a storehouse of memories to be retained over time with increasing value according to Solomon, 1985. Gordon (1991) concludes that over time 
jeans have communicated various messages and have functioned in different ways as symbols of rebellion, outlets for personal creativity, symbols of fashionable awareness and as evidence of generational longing and insecurity

\subsection{Methodology}

There were uses more emphasis on quantitative research. However, qualitative studies are used to support the study. This research is based on descriptive statistics, correlation and then followed by hypothesis testing using One-way ANOVA. Additionally, this interview will be answered of third objectives from this research. Selected informants are those who are involved in fashion and should be proficient and experienced and have deep knowledge about denim jeans especially for men in Malaysia can provide answers to research questions. Mohd Adnan bin Hassan (2018) more known as Adnan Hassan a fashion designer. The second informal interview was Afiq Iskandar Zainal Ariffin (2018) wellknown as Afiq "Amber" Iskandar a Founder of Denim Company, Tarik Jeans, CoFounder Nusantara Denims and the guitarist member of the band Oh Chentaku.

Table 2: Research Instrument (Questionnaire)

\begin{tabular}{c|l|l|l}
\hline No. & \multicolumn{1}{|c|}{ Variables } & \multicolumn{1}{c|}{ Factors } & \multicolumn{1}{c}{ Scale / Style } \\
\hline 1 & $\begin{array}{l}\text { Section A (5 items) } \\
\text { Respondent Demographic } \\
\text { Profile }\end{array}$ & $\begin{array}{l}\text { Age, race, profession, } \\
\text { salary range and } \\
\text { education }\end{array}$ & $\begin{array}{l}\text { Multiple choice } \\
\text { questions (closed } \\
\text { ended questions) }\end{array}$ \\
\hline 2 & $\begin{array}{l}\text { Section B (5 items) } \\
\text { Understanding Men's } \\
\text { Personality }\end{array}$ & $\begin{array}{l}\text { Fashion trends and } \\
\text { impact on the society }\end{array}$ & $\begin{array}{l}\text { Multiple choice } \\
\text { questions (closed } \\
\text { ended questions) }\end{array}$ \\
\hline 3 & $\begin{array}{l}\text { Section C (5 items) } \\
\text { Through Denim Jeans Cutting }\end{array}$ & $\begin{array}{l}\text { Person are interested of } \\
\text { jeans, aware of jeans } \\
\text { trends and come up } \\
\text { with personality and } \\
\text { identity }\end{array}$ & $\begin{array}{l}\text { Dichotomous } \\
\text { questions (one } \\
\text { selection) }\end{array}$ \\
\hline 4 & $\begin{array}{l}\text { Section D (10 items) } \\
\text { Denim Jeans as Reflection of } \\
\text { Self Identity }\end{array}$ & $\begin{array}{l}\text { Personality value and } \\
\text { influence of wearing } \\
\text { jeans }\end{array}$ & $\begin{array}{l}\text { Multiple selection / } \\
\text { likert scale } \\
\text { (1:strongly } \\
\text { disagree - } \\
5: \text { strongly agree) }\end{array}$ \\
\hline
\end{tabular}

Creswell (2005) also confirms that attitudes and opinions are about respondents' thinking, and practices are what respondents do. A semi-structured interview was used for the study. A total of 40 questionnaires were distributed equally to the men respondents in Kuala Lumpur. The questionnaire consisted of four sections and included categories of questions on the following: Section A (Respondent Demographic Profile), Section B (Understanding Men's Personality), Section C (Through Denim Jeans Cutting) and Section D (Denim Jeans as Reflection of Self Identity).

\subsection{Data Analysis}

The data was coded and analysed with The Statistical Package for Social Science 2.0 (SPSS) software and tools facilities. A complete frequency in per cent will be computed for the presentation of the results. Three basic objectives 
in data analysis are to get a feel for data, to test the goodness of data and to test hypotheses developed for the research. This is a quantitative measure and the result can be interpreted. Data analysis was divided into three sections using descriptive and inferential statistics;

1) The first section of the data analysis used descriptive statistics to understand or identify jeans cutting styles look good on men body. A frequency mean score and percentage data analysis will conduct in this section.

2) In the second and third section, multiple regression analysis will be applied to differentiate men select suitable styles of jeans when make selection in order to looking the relationship between independent and dependent variables. Multiple regression analysis will allow the introduction of several independent variables, so that equation constructed reflects the values of several rather than one predictor variable (Churchill, 2001).

3) Finally, frequencies and crosstab analysis for multiple responses will used to develop men's personality of self-identity reflection of jeans style.

\subsection{Results of Analysis}

As a conclusion, Personality Physiological Factors in Self-Identity were considered the most influential factor predicting on Understanding Personality of Self-identity Reflection towards Men's in Kuala Lumpur of Denim Jeans Cutting Styles. This study also indicates that the survey method in used by psychologists to learn about attitude and behaviors that cannot be directly observed in the natural setting or studied experimentally. A total of 40 questionnaires were distributed equally to the men respondents in Kuala Lumpur. Several factors such as mentioned of Maslow's Hierarchy of Needs which is self-actualization, esteem, social, safety and physiological are affects fashion on a number of levels. For this reasons, external factors played an important role in affecting of fashion.

Table 3: Frequency and percentage for statement in "Through Denim Jeans Cutting"

\begin{tabular}{|l|l|c|c|}
\hline No. & \multicolumn{1}{|c|}{ Statement } & Yes & No \\
\hline 1. & Are you a person interested of jeans? & $\begin{array}{c}35 \\
(87.5 \%)\end{array}$ & $\begin{array}{c}3 \\
(12.5 \%)\end{array}$ \\
\hline 2. & Do you understand what it means to jeans? & $28(70 \%)$ & $12(30 \%)$ \\
\hline 3. & Are you aware of the jeans trend developments? & $\begin{array}{c}29 \\
(72.5 \%)\end{array}$ & $\begin{array}{c}(27.5 \%) \\
11\end{array}$ \\
\hline 4. & $\begin{array}{l}\text { Are jeans able to come up your own identity and } \\
\text { personality? }\end{array}$ & $30(75 \%)$ & $10(25 \%)$ \\
\hline
\end{tabular}


Result from table 2 above shows that majority of the respondent agree with the statement in section C, "Through Denim Jeans Cutting" with percentage for each statement obtained at least $70 \%$ for "yes" option. The highest percentage was statement "Are you a person interested of jeans?" (87.5\%) proves that more than majority of the respondent interested of jeans, followed by question „Are jeans able to come up your own identity and personality?" with (75\%) and „Are you aware of the jeans trend developments?" (72.5\%). The lowest percentage was "Do you understand what it means to jeans?" with $70 \%$ of the respondent chose "yes" option. Result from analysis proves that slim fit jeans was the type of jeans that had a best choice among respondent, followed by straight cut jeans, skinny jeans, regular jeans and tapered jeans. For section „denim jeans as reflection of self- identity, it was found that the highest mean score recorded was statement "I like jeans as a casual wear". Correlation analysis show that there was significantly moderate positive relationship between "how often do you wear jeans?" with skinny jeans. However, there were no correlations between other "types of jeans" with each statement in "understanding men's personality". Hypothesis testing using 1 way ANOVA on „How men"s personality is 131 related of self-identity reflection of jeans styles?" shows that only statement "As what to reflect your identity when wearing a denim jeans?" has a significant relationship with self-identity reflection of jeans styles.

Today, jeans are still the most preferred by people of all ages (Dascalu, et al. 2000). Denim has many advantages as compared to other jeans material and therefore it is safe to say that the fabric will see more fashion lines as well as promote health and comfort to individuals in the future. For men, denim was often a frustrating reminder of social status but for women denim could be associated with unprecedented advancement. Denim as we know it today is instilled with all these stories even may not be able to perceive it on a daily basis. Masculinity and conceptions of gender are changing but denim warranties giving up staying current and politically correct.

Denim jeans are ultimate masculine, casual garment and most men own and wear it. They have a 'rich' history but navigating today's world ripped, faded and embellished jeans to find a pair that suit classic, yet modern tastes can be tough. As we can see, today blue jeans are a billion-dollar industry grossing more than $\$ 15$ billion In the United States alone which only accounts for less than $40 \%$ of global purchases (Kyle, 2019). Jeans have also undergone a rather significance change in styles over the years including the bell-bottom craze of the 70's and now the tapered skinny jeans trend. Many of characteristics that make denim jeans are super legend such as their cut and fit, color, wash and fading and material. Because of that, jeans are possibly the most popular trouser in the world and also the perfect pair of pants for the outdoors, running errands, casual get-togethers and very casual office settings.

\subsection{Conclusion}

Result from analysis proves that slim fit jeans was the type of jeans that had a best choice among respondent, followed by straight cut jeans, skinny jeans, regular jeans and tapered jeans. For section 'denim jeans as reflection of self- identity, it was found that the highest mean score recorded was statement 'I like jeans as a casual wear'. 
Correlation analysis show that there was significantly moderate positive relationship between 'how often do you wear jeans?' with skinny jeans. However, there were no correlation between other 'types of jeans' with each statement in 'understanding men's personality'. Hypothesis testing using 1 way ANOVA on 'How men's personality is related of self-identity reflection of jeans styles?' shows that only statement 'As what to reflect your identity when wearing a denim jeans?' has a significant relationship with self-identity reflection of jeans styles.

In summary, jeans have evolved to be the most popular type of clothing since the 1990s. Denim has become a most popular fashion trend. In fact, the denim apparel market grew $5.0 \%$ and $6.8 \%$ in unit sales and dollar sales respectively in 2004 (Denim, 2005). Alba (2012), elaborating that the relation between fashion and identity is one of representation and fashion may represents identity. Fashion such denim jeans is one"s personality on the outside which means it is who you are inside but on the outside because the representation of identity is closely linked to the idea of image. On this interpretation, after the garments have established and represented one"s identity is be there in any reference to other in different identities. As stated, in a development of denim jeans factors are beginning of introduction of denim jeans by concluded technique and method also a chronology history of blue denim year by years may gained understanding personality towards men in Kuala Lumpur. There is nothing more unique than the "magical" of denim jeans which has been used for many centuries ago from baby boomers, Generation $X$ and Generation $Y$ until today where acknowledged the existence and the privilege of each individual.

\section{References}

Antonio, C. (2012-2019). Dress to Impress "The Fit Man Collective Interview with Antonio Centeno". An Elite CafeMedia Lifestyle Publisher.

Berger, A. (2009). What Objects Mean. An Introduction to Material Culture. Walnut Creek: Left Coast Press.

Bob, P. (1988). An Exercise in Personal Exploration: Maslow's Hierarchy of Needs by Cst

Bramley, E. V. (2015). In Tune. Creative Review, 35 (5), 42-46.

Cattell, R. B. Eber, H. W., \& Tatsouoka, M. M. (1970) Handbook for the 16 F. Champaign, IL: Institute for Personality and Ability Testing.

Combs, A. W., \& Snygg, D. (1959). Individual Behavior (Rev. ed.). New York, NY: Harper \& Row.

Daniel, M. Sophie W., (2007). Manifesto for A Study of Denim. Social Anthropology Volume 15, Issue 3.

Emma, S. (2017). Innovation at the Intersection of Fashion and Technology by Brandwatch.

Ewen, S. \& Ewen. E. (1992). Channels of Desire: Mass Images and the Shaping of American 
Consciousness. Minneapolis: University of Minnesota Press.

Fashion, Costume and Culture, $2^{\text {nd }}$ Edition (2000).

Fibre2Fashion (2013). Transition of Choice from Traditional Wear to Jeans. Fibre2Fashion.com, World of Garment. Textile. Fashion.

Gordon, B (1991). American Denim: Blue Jeans and Their Multiple Layers of Meaning, In Cunningham, \& S V) Lab (Eds), Dress and Popular Culture, page 31-45, Bowling Green: Bowling Popular Press.

Hanson, William E.,Creswell, John W.,Clark, Vicki L. Plano,Petska, Kelly S.,Creswell, J. David (2005). Mixed Methods Research Designs in Counseling Psychology.

Hazita Azman, Bahiyah Abdul Hamid \& Zarina Othman (2011). Malaysian Youth in the Global World: Issues and Challenges. Universiti Kebangsaan Malaysia.

Kluckhohn, C., Murray, H.A., \& Schneider, D.M. (1948). Personality in Nature, Society and Culture ( $2^{\text {nd }}$ ed. rev), Oxford, England: Knopf.

Matthews, G., Deary, I. J., \& Whiteman, M. C. (2003). Personality traits (2nd edition). Cambridge, England: Cambridge University Press. Matthews, G., Schwean,V. L., C

Riley, R. Reese (2017). Music \& Fashion: Intertwined Throughout the Ages. Jerrick Ventures LLC.

Soh, K. -L., Jayaraman, K., Choo, L.-P., \& Kiumarsi, S. (2015). The Impact of Background Music on The Duration of Consumer Stay at Stores: An Empirical Study in Malaysia. International Journal of Business and Society, 16(2), 247-260

Sullivan, J. (2006). Jeans: A Cultural History of an American Icon. New York: Gotham Press

Zaimah (2017). "Ini Subculture yang Pernah Popular di Malaysia Sebelum Adik-Adik Raver Dilahirkan". Copyright Iluminasi.com. 